\title{
Increasing Ethanol Titer and Reducing Enzyme Dosage via Fed-Batch, Simultaneous Saccharification and Fermentation in a High Solids Bioreactor
}

\author{
Nichole A. Bauer, ${ }^{1}$ Craig C. Long, ${ }^{1}$ Bishnu Karki, ${ }^{1}$ and William R. Gibbons ${ }^{2}$ \\ ${ }^{1}$ Biology-Microbiology Department, South Dakota State University, Brookings, SD 57007, USA \\ 2 Biology-Microbiology Department, South Dakota State University, Brookings, SD 57007, USA, \\ william.gibbon@sdstate.edu, 605-688-5499, (F) 605-688-6677
}

\begin{abstract}
Fed-batch, solid state, simultaneous saccharification and fermentation (SSF) was evaluated as an approach to reduce enzyme use in converting cellulose to ethanol, and to maximize ethanol titer. Kraft pulp, an intermediate in paper production, was used to represent a fractionated cellulose feedstock. Following a literature survey, average dosages were determined as 34 FPU of cellulase (Celluclast 1.5L) and $135 \mathrm{CBU}$ of $\beta$ glucosidase (Novozyme 188) per gram glucan, and were set as $100 \%$ dosages. Initially, submerged fed-batch SSF trials were conducted in a traditional bioreactor using enzyme dosages of $17,33,67$, and $133 \%$, with a final solids loading rate (SLR) of 14\%. Ethanol production was similar (77.3-83.4\% of theoretical yield) for trials with 33-133\% enzyme dosages, but fell to 36\% of theoretical at $17 \%$ enzyme dosage. Fed-batch saccharification and fed-batch SSF were then performed in a solid state bioreactor, achieving a 34.8\% SLR. This reduced the initial $133 \%$ enzyme dosage to $19 \%$. In saccharification trials the glucose yield was only $35 \%$ of theoretical $(103.6 \mathrm{~g} / \mathrm{L})$, due to feedback inhibition of enzymes. Companion SSF trials achieved an ethanol yield of only $20 \%$ of theoretical $(30.1 \mathrm{~g} / \mathrm{L}$ ethanol). While some ethanol was lost due to evaporation, yeast inhibition by low water activity was presumed to be the primary limitation. Performance at lower solid loading rates were evaluated, and even diluted the fermented slurry and conducted a secondary fermentation. These trials suggest that enzyme inactivation via irreversible binding may be the primary limitation, instead of low water activity or nutrient limitation.
\end{abstract}

Keywords: Saccharification, Cellulose, Ethanol, Solid state reactor, Fed-batch fermentation

(C) Copyright 2014 Authors - This is an Open Access article published under the Creative Commons Attribution License terms (http://creativecommons.org/licenses/by/3.0). Unrestricted use, distribution, and reproduction in any medium are permitted, provided the original work is properly cited.

Date Received: 2014-03-10

Date Accepted: 2014-09-03

Date Published: 2014-09-30

\section{Introduction}

Submerged bioreactors have traditionally been used for fermentation processes, including large scale systems common in corn ethanol facilities. Submerged bioreactors allow for precise control of temperature, $\mathrm{pH}$, agitation, aeration, and mass transfer. The chief limitation is viscosity of the fermentation broth, as this limits mixing/mass transfer, and dramatically increases agitation energy requirements [1]. Thus, the solids loading rate in submerged bioreactors is limited by flow characteristics of the slurry and the forces exerted on the motor and impellers. Different types of solids can result in significantly different flow properties, even at the same solid loading rate [2]. For example, corn ethanol production typically employs $>30 \%$ solid loading rate to achieve ethanol titers of $>150 \mathrm{~g} / \mathrm{L}$. However because lignocellulosic biomass has a much lower bulk density, it is estimated that submerged bioreactors will only accommodate $10-15 \%$ solid loading, resulting in ethanol titers of 40-60 g/L [3]. These dilute, slurries will require substantially larger bioreactor volumes (and operational costs) along with greater energy input for ethanol recovery.

Another option for dealing with low bulk density feedstocks is to perform an initial saccharification of a dilute slurry, then remove the non-fermentable through filtration or centrifugation, and finally concentrate liquid through evaporation to achieve a clean solution with the desired sugar concentration for fermentation. One disadvantages of this method would be feedback inhibition of the enzymes during saccharification, resulting in incomplete sugar release $[4,5]$. Also, if the non-fermentable solids are not washed, some sugar will be lost with these solids. The other major disadvantage of this approach would be the large amounts of energy 
necessary to concentrate the sugar solutions, especially if solids are washed.

An alternative to these methods is solid state conversion, in which a minimum amount of water is added, so simultaneous saccharification and fermentation (SSF) occur in the liquid film on solid particles [6,7]. This would maximize solids loading and ethanol concentration, while minimizing energy needed for ethanol recovery [8]. There are many advantages of using a solid state fermentation system: lower production cost, less energy needed, and greater fermentation productivity [9]. Gibbons et al $[10,11]$ used solid state fermentation to convert sweet sorghum and fodder beet pulp to ethanol achieving ethanol yields of $85 \%$ and $78-85 \%$ of theoretical, respectively. Moukamnerd et al [9] used a solid state fermentation system to convert raw corn starch to ethanol. Ethanol was recovered continuously, with an ethanol yield of 93\%. The purpose of the project herein was to compare submerged bioreactors versus solid state bioreactors at various solid loading rates of a cellulosic substrate. The goal was to minimize enzyme use, while maximizing ethanol production.

\section{Materials and Methods}

\subsection{Enzymes, Yeast, Substrate, and Other Materials}

Enzymes used in this study were obtained as a gift from Novozymes. Celluclast $1.5 \mathrm{~L}$ is a cellulase enzyme and has an activity of $4460.6 \mathrm{EGU} / \mathrm{ml}$. Novozyme 188 is a $\beta$-glucosidase and has an activity of $18,150 \mathrm{CBU} / \mathrm{ml}$. Enzymes were stored at $4{ }^{\circ} \mathrm{C}$. Previously, we surveyed the literature and calculated the average dosage for Celluclast 1.5L (34 FPU /g glucan) and Novozyme 188 (135 CBU /g glucan) $[12,13]$. These dosages were set as $100 \%$, and then we evaluated higher and lower enzyme dosages based on these literature values.

Saccharomyces cerevisiae NRRL Y-2034 was provided by the USDA National Center for Agricultural Utilization Research, Peoria, IL. For short term maintenance the yeast was stored on Potato Dextrose Agar Plates (PDA) plates and slants at $4{ }^{\circ} \mathrm{C}$. Lyophilization was used for long term storage. Inoculum for all experiments was prepared by transferring colonies into a $5 \%$ glucose, $0.5 \%$ yeast extract broth (100 $\mathrm{ml}$ in 250 Erlenmeyer flasks), then incubating for $24 \mathrm{~h}$ at $35{ }^{\circ} \mathrm{C}$ in a $250 \mathrm{rpm}$ rotary shaker. Cell counts of the inoculum were nominally in the $3-6 \times 10^{8} \mathrm{CFU} / \mathrm{ml}$ range.

Kraft pulp was used as the substrate and was obtained as a gift from the Paper Science and Engineering Department at the University of Wisconsin
- Stevens Point, and consisted of: $76.7 \%$ glucan, $0.5 \%$ arabinan, $7.7 \%$ xylan, $0.3 \%$ galactan, $6.7 \%$ mannan, and $3.2 \%$ lignin. The buffer solution consisted of $34.4 \mathrm{~g}$ sodium citrate per liter of distilled water. The $\mathrm{pH}$ was adjusted to 4.8 using $14 \mathrm{M} \mathrm{HCl}$. A stock solution of tetracycline $(10 \mu \mathrm{m} / \mathrm{ml}$ in $70 \%$ ethanol) was prepared and stored in the freezer. To control contamination, 5.3$6 \mathrm{ml}$ of the tetracycline solution was added per liter of fermentation broth. Condensed corn solubles (CCS) was added as a low cost nutrient source for the yeast, and was obtained as a gift from a dry mill ethanol plant. Table 1 shows an analysis of CCS.

Table 1. Composition of Condensed Corn Solubles (CCS)

\begin{tabular}{|c|c|c|}
\hline Parameters & $\begin{array}{c}\text { As Received } \\
\text { Basis }\end{array}$ & $\begin{array}{c}\text { Dry } \\
\text { Basis }\end{array}$ \\
\hline Total Moisture, \% & 72.3 & 0 \\
\hline Total Dry Matter, \% & 27.7 & 100 \\
\hline $\begin{array}{c}\text { Crude Protein, } \\
\text { Combustion, \% }\end{array}$ & 5.25 & 18.9 \\
\hline $\begin{array}{c}\text { Crude Fat (Diethyl Ether } \\
\text { Extract), \% }\end{array}$ & 5.71 & 20.6 \\
\hline Ash, \% & 3.28 & 11.9 \\
\hline Fat: Roese Gottieb, \% & 5.71 & 20.6 \\
\hline $\begin{array}{c}\text { Crude Fiber, Crucible } \\
\text { Method, \% }\end{array}$ & 0.48 & 1.74 \\
\hline $\begin{array}{c}\text { Nitrogen Free Extract, } \\
\%\end{array}$ & 13.0 & 47.0 \\
\hline Calcium, \% & 0.03 & 0.10 \\
\hline Copper, ug/g (ppm) & 1.20 & 4.34 \\
\hline Magnesium, \% & 0.22 & 0.80 \\
\hline Phosphorus, \% & 0.46 & 1.66 \\
\hline Potassium, \% & 0.77 & 2.70 \\
\hline Sodium, \% & 0.20 & 0.74 \\
\hline Zinc, ug/g (ppm) & 29.9 & 108 \\
\hline
\end{tabular}

\subsection{Effects of Enzyme Dosage on Fed-batch Submerged SSF of Kraft Pulp}

Trials in triplicate were conducted in a $5 \mathrm{~L} \mathrm{New}$ Brunswick BioFlow III bioreactor to determine if fedbatch additions of kraft pulp could be made without the need for additional enzymes. The top portion of Table 2 lists the components initially added to bioreactors for 
treatments, resulting in final enzyme dosages of 17 $133 \%$ of the literature average. Each bioreactor was also charged with $5.3 \mathrm{ml}$ tetracycline solution, $10 \mathrm{~g}$ CCS and $20 \mathrm{ml}$ of $S$. cerevisiae. The temperature was set at $35{ }^{\circ} \mathrm{C}$ and the agitation rate was initially set to $900 \mathrm{rpm}$ so adequate mixing was achieved. After $\sim 30 \mathrm{~min}$ the broth became less viscous, and the agitation rate was reduced to 75-100 rpm. The bottom portion of Table 2 lists the components added at 3,6 , and $24 \mathrm{~h}$ during the fed-batch process. The total volume of all trials was $2,856 \mathrm{ml}$, resulting in a total solid loading rate (SLR) of 14\%.

Table 2. Materials for Fed-batch Submerged Fermentation

\begin{tabular}{|c|c|c|c|c|}
\hline Materials Used & \multicolumn{3}{|c|}{ Treatment (Effective Enzyme Dosage) } \\
\hline Components added initially & $133 \%$ & $67 \%$ & $33 \%$ & $17 \%$ \\
\hline Buffer (ml) & 1965 & 2127 & 2307 & 2364 \\
\hline Celluclast 1.5L (ml) & 216 & 108 & 54 & 27 \\
\hline Novozyme 188 (ml) & 240 & 120 & 60 & 30 \\
\hline Kraft pulp (g) & 100 & 100 & 100 & 100 \\
\hline Kraft pulp (g) & 100 & 100 & 100 & 100 \\
\hline Celluclast 1.5L (ml) & 54 & 27 & 0 & 0 \\
\hline Novozyme 188 (ml) & 60 & 30 & 0 & 0 \\
\hline Buffer (ml) & 0 & 0 & 114 & 114 \\
\hline
\end{tabular}

\subsection{Fed-batch Saccharification in a Solid State Bioreactor}

To assess the performance of a solid state bioreactor we constructed, initial trials were performed in triplicate using fed-batch saccharification. The reactor (Figure 1) has a $16 \mathrm{~L}$ internal capacity with a horizontal shaft and paddles driven by a $0.373 \mathrm{~kW}$ variable speed motor (20-60 rpm). The reactor was placed within a static incubator for temperature control. The bioreactor was initially loaded with $1,380 \mathrm{ml}$ of sodium citrate buffer, $54 \mathrm{ml}$ of cellulase enzyme, $60 \mathrm{ml}$ of $\beta$-glucosidase enzyme, $6 \mathrm{ml}$ of tetracycline solution, and $100 \mathrm{~g}$ of kraft pulp. This provided an initial enzyme dosage of 133\% and a SLR of $15 \%$. The temperature was set to $35{ }^{\circ} \mathrm{C}$ instead of $50{ }^{\circ} \mathrm{C}$, so the results would be more directly comparable to subsequent SSF trials. The agitation rate was set to $60 \mathrm{rpm}$, and saccharification was performed for $96 \mathrm{~h}$. At 3, 6, and $9 \mathrm{~h}, 100 \mathrm{~g}$ of kraft pulp were added, and at 24 and 36 h, 200 g of kraft pulp were added, resulting in a final SLR of $34.8 \%$ and a final volume of 2,300 L. No additional enzymes were added, resulting in a final enzyme dosage of $19 \%$.


Figure 1. Solid State Bioreactor 


\subsection{Fed-batch SSF in a Solid State Bioreactor}

Initial fed-batch SSF trials were performed in triplicate following a similar protocol to that described above for fed-batch saccharification, except that all components were proportionally increased to achieve a final volume of $12 \mathrm{~L}$. The second column of Table 3 lists the materials used in the $34.8 \%$ SLR trial and the final enzyme dosage. A $24 \mathrm{~h}$ yeast inoculum and CCS (to supply yeast nutrients) were also added initially.
Temperature and agitation were set to $35^{\circ} \mathrm{C}$ and $60 \mathrm{rpm}$, respectively, for the $96 \mathrm{~h} \mathrm{SSF}$. Due to inadequate conversion efficiency in the $34.8 \%$ SLR trial, presumably caused by low water activity, we gradually reduced the total SLR in subsequent trials as shown in the remaining columns of Table 3 . We also tested a 14\% SLR for comparison with the fed-batch SSF trials in the submerged bioreactor.

Table 3. Materials for Fed-batch Solid State SSF

\begin{tabular}{|c|c|c|c|c|c|}
\hline & \multicolumn{5}{|c|}{ Solid Loading Rates } \\
\hline Materials & $\mathbf{3 4 . 8 \%}$ & $\mathbf{2 7 \%}$ & $\mathbf{2 5 \%}$ & $\mathbf{2 1 \%}$ & $\mathbf{1 4 \%}$ \\
\hline Cellulase (ml) & 282 & 70.5 & 65.28 & 54.84 & 36.56 \\
\hline 3- glucosidase (ml) & 313 & 78.25 & 72.45 & 60.86 & 40.57 \\
\hline Buffer (ml) & 7020 & 1988.5 & 2059.52 & 2201.55 & 2450.12 \\
\hline Tetracycline (ml) & 31 & 7.75 & 7.75 & 7.75 & 7.75 \\
\hline Yeast (ml) & 120 & 30 & 30 & 30 & 30 \\
\hline CCS (ml) & 60 & 15 & 15 & 15 & 15 \\
\hline Kraft Pulp - initial (g) & 521.75 & 101.25 & 93.75 & 78.75 & 52.5 \\
\hline Kraft Pulp additions - 3, 6, 9 h (g) & 521.75 & 101.25 & 93.75 & 78.75 & 52.5 \\
\hline Kraft Pulp additions - 24 \& 36 h (g) & 1043.50 & 202.5 & 187.5 & 157.5 & 105 \\
\hline Final Enzyme Dosages & $19 \%$ & $20 \%$ & $22 \%$ & $26 \%$ & $39 \%$ \\
\hline Total Volume & $12 \mathrm{~L}$ & $3 \mathrm{~L}$ & $3 \mathrm{~L}$ & $3 \mathrm{~L}$ & $3 \mathrm{~L}$ \\
\hline
\end{tabular}

\subsection{Secondary Analysis of Fed-Batch, Solid State SSF Samples}

To quantify the level of un-hydrolyzed cellulose remaining in the kraft pulp slurries at $0,24,48,72$, and $96 \mathrm{~h}$, samples were collected and subjected to an additional saccharification. Each $5 \mathrm{ml}$ sample of fermentation broth was blended with $89.3 \mathrm{ml}$ of buffer in a stoppered, $250 \mathrm{ml}$ Erlenmeyer flask. After autoclaving to kill the yeast, $2.7 \mathrm{ml}$ of cellulase and $3 \mathrm{ml}$ of $\beta$ glucosidase were added (133\% enzymes dosage) to the cooled slurry, which was incubated at $250 \mathrm{rpm}$ at $50{ }^{\circ} \mathrm{C}$ for $72 \mathrm{~h}$. Glucose levels were determined by HPLC analysis at 0 and $72 \mathrm{~h}$, and difference was used to calculate the amount of un-hydrolyzed cellulose present.

During the fed-batch SSF trials in the solid state bioreactor we noted high levels of glucose and lower levels of ethanol than we expected. We hypothesized that either nutrients or water activity may have limited yeast metabolism. Therefore samples were collected at $96 \mathrm{~h}$ SSF and were subjected to the following tests. In one set of $500 \mathrm{ml}$ Erlenmeyer flasks, varying amounts of buffer were added $(10,25,50$ or $100 \mathrm{ml})$ to 100 g quantities of fermented pulp to determine if water activity was limiting. In a separate flask, $49 \mathrm{ml}$ of buffer and $1 \mathrm{~g}$ of yeast extract were added to $100 \mathrm{~g}$ of fermented pulp to determine if nutrients were limiting. These flasks were incubated an additional $72 \mathrm{~h}$ at $35^{\circ} \mathrm{C}$ in a rotary shaker (250 rpm), with HPLC analysis at 0 and $72 \mathrm{~h}$.

\subsection{Analytical Methods}

Samples (5 ml) were removed at $0,3,6,9,12,24$, $36,48,72$, and $96 \mathrm{~h}$ during the trials. To ensure sample uniformity, samples were collected with $10 \mathrm{ml}$ wide mouth pipets. Samples were placed in sealed centrifuge tubes and boiled for five min to denature enzymes. Samples were the filtered through $0.2 \mu \mathrm{m}$ filters into auto-sampler vials which were frozen until analysis. Carbohydrates, organic acids, and ethanol were measured in a Waters HPLC, with an Aminex HPX-87H column, and Waters 2410 refractive index detector. The mobile phase was $0.01 \mathrm{~N} \mathrm{H}_{2} \mathrm{SO}_{4}$ at a flow rate of $0.6 \mathrm{ml}$ per minute.

\section{Results and Discussion \\ 3.1. Effects of Enzyme Dosage on Fed-Batch Submerged SSF of Kraft Pulp}

A 14\% SLR of kraft pulp was used to evaluate fedbatch submerged SSF at enzyme dosages of 133, 67, 33, 
and $17 \%$ of the average listed in the literature. Based on the glucan content of the kraft pulp, the theoretical yields of glucose and ethanol were $120.9 \mathrm{~g} / \mathrm{L}$ and $61.7 \mathrm{~g} / \mathrm{L}$, respectively. Figure 2 shows the average ethanol concentrations of these four enzyme dosages during the $96 \mathrm{~h}$ SSF period. Final ethanol titers of $\sim 48-51 \mathrm{~g} / \mathrm{L}$ were achieved with enzyme dosages of 133\%, 67\%, and 33\%. These represented ethanol yields of $77-83 \%$ of theoretical and indicated that enzyme dosage could be safely reduced to $33 \%$ of the literature average $(11.25$ FPU cellulase and $45 \mathrm{CBU} \beta$-glucosidase per gram glucan). We do not have an explanation for the delayed ethanol production observed in the 133\% enzyme dosage trial, but this trend was consistent for all replications. Maximum ethanol titer $(22.23 \mathrm{~g} / \mathrm{L})$ and theoretical yield (36\%) at the $17 \%$ enzyme dosage demonstrated that this level was insufficient for effective SSF.

Glucose concentrations during fermentation showed a typical early peak, since enzymatic saccharification rates initially exceed glucose consumption rates during the yeast growth phase (data not shown). After $24 \mathrm{~h} \mathrm{SSF}$, glucose levels were minimal, and final residual glucose levels were $0.43-2.24 \mathrm{~g} / \mathrm{L}$ in all trials. Cellobiose was not detected during SSF, while xylose (2.84-5.55 g/L) accumulated during fermentation, with higher concentrations in the higher enzyme dosage trials (data not shown). This was expected, since the $S$. cerevisiae strain Y-2034 cannot metabolize xylose [14].

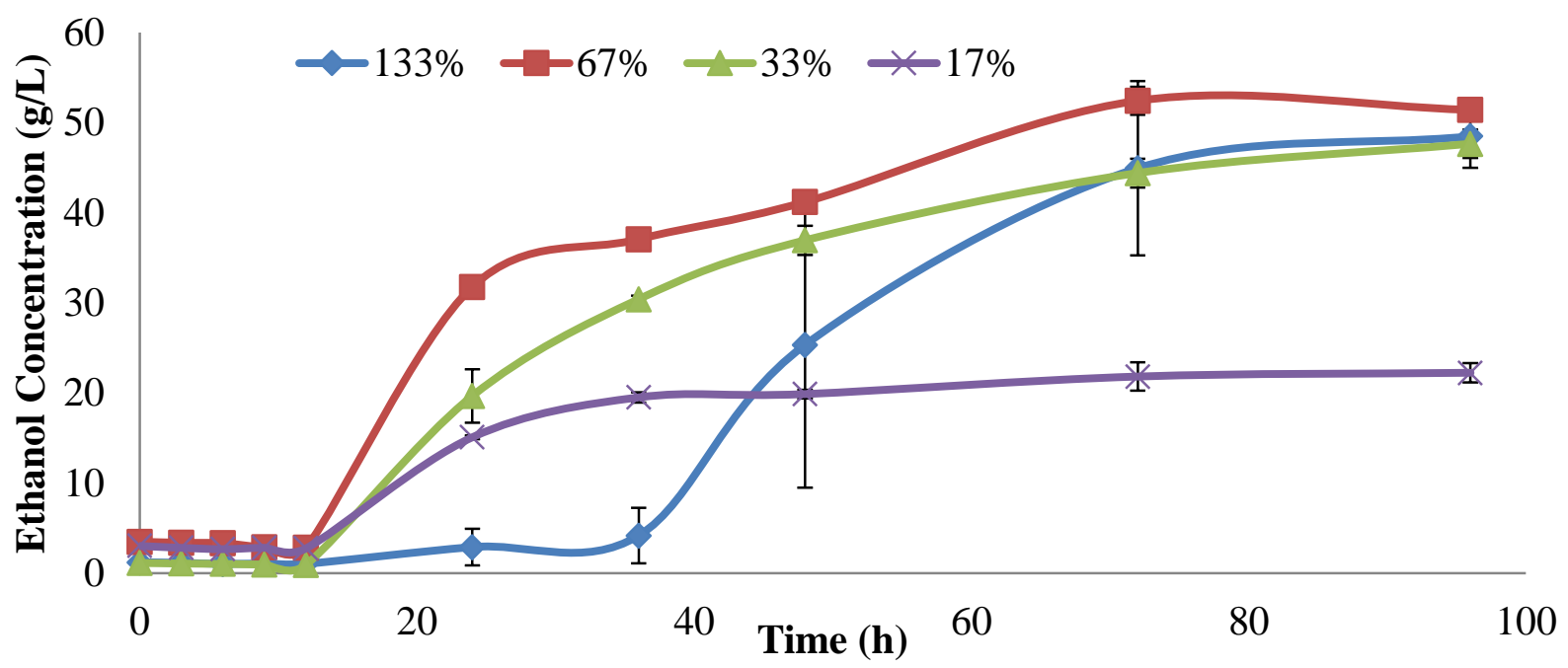

Figure 2. Ethanol Concentration during Fed-batch SSF of Kraft Pulp at 133\%, 67\%, 33\%, and 17\% Enzyme Dosages (100\% enzyme dosage: 34 FPU cellulase and $135 \mathrm{CBU} \beta$-glucosidase $135 \mathrm{CBU}$ per gram glucan)

Table 4 lists the maximum ethanol titer, productivity, and residual glucose levels for these trials. As discussed above, the onset of ethanol production was delayed in the $13 \%$ enzyme dosage trial. This was correlated with a higher and more variable residual glucose titer. Thus it is possible that some unknown factor inhibited yeast metabolism in this treatment. These parameters are similar for enzyme dosages above $33 \%$, showing that fed-batch SSF is an effective mechanism to reduce enzyme dosage $[4,15]$. Kuhad et al. [4] also found that fed-batch feeding of substrate (deinked newsprint) during SSF allowed an increase in SLR (from $2 \%$ to $6 \%$ ), resulting in $14.78 \mathrm{~g} / \mathrm{L}$ ethanol $(85 \%$ yield) based on the $51 \%$ cellulose content of the newspaper. However, their final enzyme dosages (cellulase at $115 \%$ and $\beta$-glucosidase at $87 \%$ of the literature average) were significantly higher than used herein. Ballesteros et al. [15] used fed-batch feeding of recycled paper at $42^{\circ} \mathrm{C}$ to increase SLR from 5 to $10 \%$. At a final enzyme dosage of $100 \%$ of the literature average for cellulase they obtained an ethanol yield of 79.7\%. In the trials reported herein, enzyme dosage was reduced to $33 \%$ at a higher SLR (14\%), and still achieved approximately the same ethanol yield (77\%) 
Table 4. Comparison of Yeast Performance at Different Enzyme Dosages during Fed-Batch Submerged SSF

\begin{tabular}{|l|l|l|l|}
\hline $\begin{array}{l}\text { Net Enzyme Dosage } \\
\text { (\% of literature } \\
\text { average) }\end{array}$ & $\begin{array}{l}\text { Maximum Ethanol Titer } \\
\text { (g/L) }\end{array}$ & $\begin{array}{l}\text { Ethanol Productivity } \\
\text { (g/L/h) }\end{array}$ & $\begin{array}{l}\text { Residual Glucose } \\
\text { (g/L) }\end{array}$ \\
\hline 133 & $48.50( \pm 3.5)$ & $0.51( \pm 0.04)$ & $2.24( \pm 1.66)$ \\
\hline 67 & $51.42( \pm 0.99)$ & $0.54( \pm 0.01)$ & $0.64( \pm 0.06)$ \\
\hline 33 & $47.65( \pm 1.6)$ & $0.50( \pm 0.02)$ & $0.43( \pm 0.01)$ \\
\hline 17 & $22.23( \pm 1.1)$ & $0.23( \pm 0.01)$ & $0.49( \pm 0.1)$ \\
\hline
\end{tabular}

a At 96 hours

\subsection{Fed-batch Saccharification in Solid State Bioreactor}

To determine if lower enzyme dosages would work at an even higher SLR (34.8\%), fed-batch saccharification was conducted in the solid state, paddle type bioreactor. Initial enzyme dosages were $133 \%$ of the literature average, but since no additional enzymes were added during saccharification, the final enzyme dosage was $19 \%$ of the literature average. Incubation was conducted at $35^{\circ} \mathrm{C}$ instead of the normal $50^{\circ} \mathrm{C}$ so the results would be more comparable to subsequent SSF trials. Based on the solids loading and glucan content of the kraft pulp, the theoretical amount of glucose available was $296.1 \mathrm{~g} / \mathrm{L}$. Figures 3A and 3B show the saccharifiying mixture within the solid state bioreactor immediately before and after the third additions of 100 $\mathrm{g}$ of kraft pulp at $6 \mathrm{~h}$. By $9 \mathrm{~h}$ the pulp liquefied sufficiently so that an additional $100 \mathrm{~g}$ of kraft pulp could be added. Similar trends of viscosity reductions occurred following the remaining kraft pulp additions at $9 \mathrm{~h}(100 \mathrm{~g})$ and 24 and $36 \mathrm{~h}$ (200 g each). Thus the solid state bioreactor design was effective in mixing to at least $34.8 \%$ total SLR.

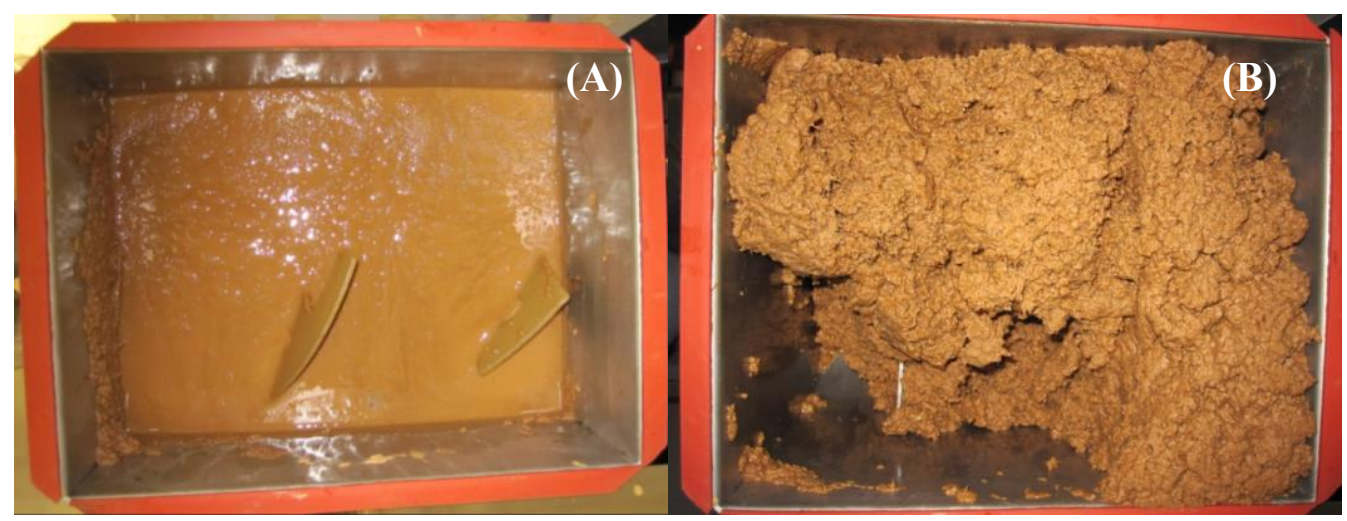

Figure 3. Kraft Pulp Slurry at 6 h: A) before loading; B) after loading

The maximum glucose level during saccharification was $103.6 \mathrm{~g} / \mathrm{L}$, which was achieved by $48 \mathrm{~h}$, and represented $35 \%$ of the theoretical yield (Figure 4). Cellobiose levels also peaked at $\sim 48 \mathrm{~h}$, reaching $28 \mathrm{~g} / \mathrm{L}$. Dextrin (DP4) levels were relatively low
(10-13 g/L) throughout. These finding were not unexpected, as it is known that cellulose deconstructing enzymes are inhibited by the build of up glucose and cellobiose $[4,5]$. Low levels of xylose were expected, since kraft pulp contains low levels of xylan. 


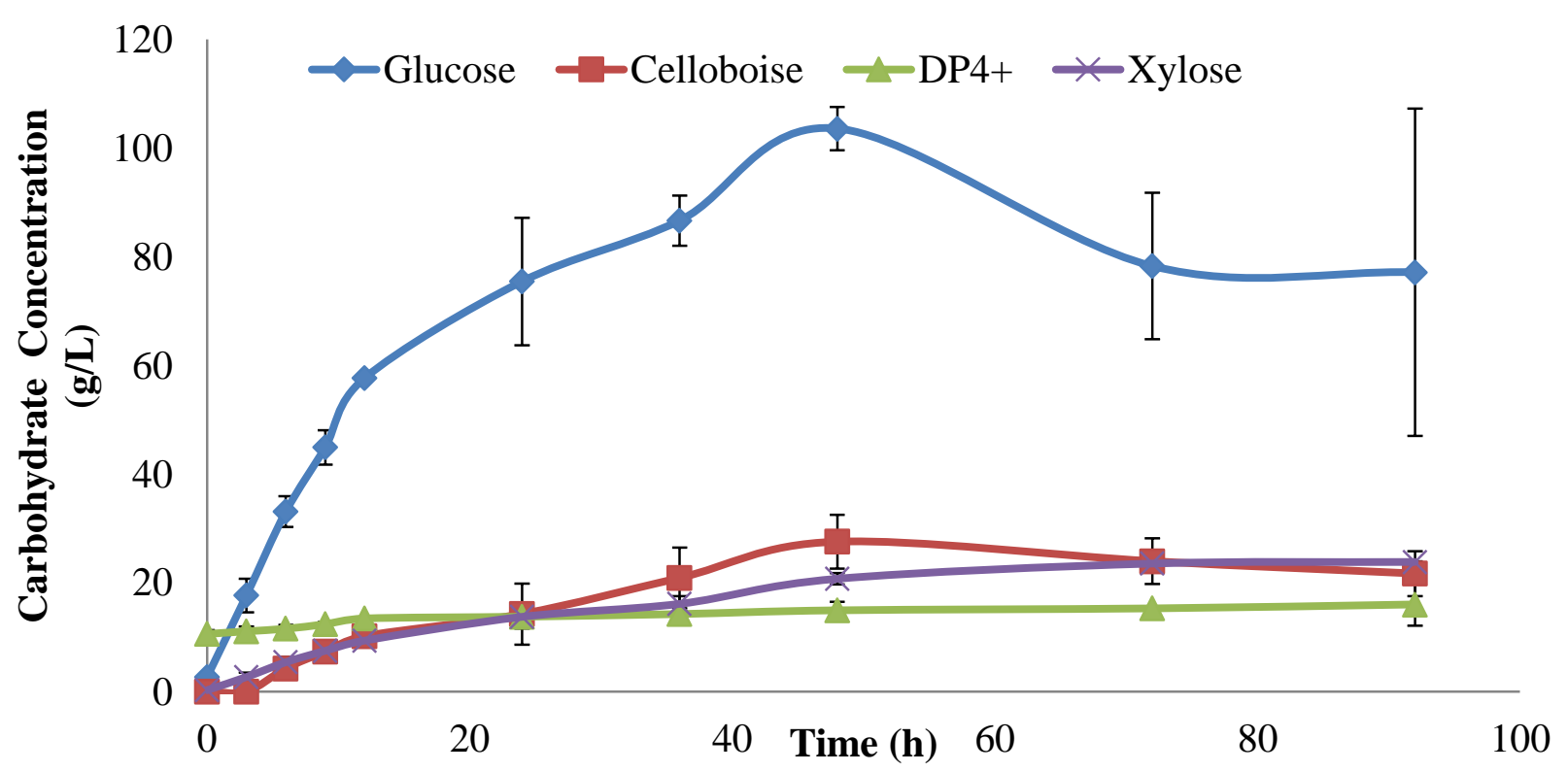

Figure 4. Carbohydrates Released from Kraft Pulp during Fed-batch, Solid State Saccharification

Using dilute acid pretreated corn stover, Rochel et al. [16] achieved $62 \%$ glucose yield after $96 \mathrm{~h}$ of batch saccharification $\left(48^{\circ} \mathrm{C}\right)$ in a horizontal paddle-type reactor at a lower SLR of $20 \%$ (compared to $34.8 \%$ in our trials). Based on the literature average, their enzyme dosages were $28 \%$ for cellulase (Spezyme CP), compared to $19 \%$ in our trials. Jorgensen et al [17] achieved a $38 \%$ glucose yield after $96 \mathrm{~h}$ of batch saccharification of hot water treated wheat straw at $35 \%$ SLR, but their cellulase dosage was higher, at $25-40 \%$ of the literature average. Therefore, using a higher cellulose content feedstock, similar results to Jorgensen et al [17] were achieved at the same solids loading, but using half as much enzyme, and at a lower temperature.

\subsection{Fed-batch SSF in a Solid State Bioreactor}

Fed-batch SSF (following the same protocol as described above, except that $S$. cerevisiae was added at 0 h) was next conducted to assess whether conversion yields could be improved by continuously converting glucose into ethanol to minimize enzyme repression [8]. The first trial was conducted at a $34.8 \%$ SLR, with subsequent trials performed at SLR of 27, 25, 21, and $14 \%$ to reduce potentially adverse impacts of low water activity. Based on the glucan content of kraft pulp, the theoretical ethanol yield for the 34.8\% SLR trial was 151 $\mathrm{g} / \mathrm{L}$, and progressively less for the other SLRs tested. Figure 5 shows the residual glucose levels, while figure 6 shows ethanol titers for these trials. Glucose levels rose during the first $12 \mathrm{~h}$ (yeast growth stage), but then fell as ethanol production began. However at $24 \mathrm{~h}$ in the $34.8 \%$ solid loading rate, glucose levels again began to rise, and continued to increase at approximately the same rate until peaking at $72 \mathrm{~h}(\sim 70 \mathrm{~g} / \mathrm{L})$. This indicated that yeast metabolism was repressed, perhaps by the combination of low water activity and high ethanol titer [5]. In the other SLR trials, glucose levels fell to $\sim 0 \mathrm{~g} / \mathrm{L}$ by $96 \mathrm{~h}$. Ethanol titers rose throughout incubation for all trials, then slowed as yeast metabolism was reduced. The highest ethanol titers of 48-50 g/L were obtained in the 25 and $27 \%$ SLR trials. This trend is also reflected in figure 7 , which shows that ethanol yield in these trials was $42-44 \%$ of theoretical.

During the $96 \mathrm{~h}$ of SSF in the solid state reactor we noted a strong evaporative loss of ethanol. This was most noticeable during sample removal and addition of fresh kraft pulp, but because it was not possible to completely seal the lid of the reactor, ethanol was continuously volatilized. We believe this is the primary reason for the differences observed between the prior submerged SSF trial at 14\% SLR (47.65 g/L ethanol, $77.2 \%$ yield at 33\% enzyme dosage) and the comparable $14 \%$ SLR trial in the solid state reactor $(30 \mathrm{~g} / \mathrm{L}$ ethanol, $48.6 \%$ yield at $39 \%$ enzyme dosage). If this $\sim 37 \%$ loss in ethanol is applied to the $25-27 \%$ SLR trials, maximal ethanol titers and yields would have increased to $67 \mathrm{~g} / \mathrm{L}$ and 59\%.

The kraft pulp slurry was monitored for unhydrolyzed cellulose at $0,24,48,72$, and $96 \mathrm{~h}$ by 
subjecting samples to autoclaving (to kill yeast), followed by dosing with enzyme and conducting an additional $72 \mathrm{~h}$ saccharification. Significant levels of cellulose were present throughout SSF for all SLR trials (data not shown), along with the high glucose levels shown in the $34.8 \%$ SLR trial. Unfortunately, due to moisture loss (ethanol and water) from the solid state pulp during autoclaving, it was not possible to calculate the percent conversion of cellulose. However this demonstrated that cellulose hydrolysis was limited by some factor in the solid state SSF process.

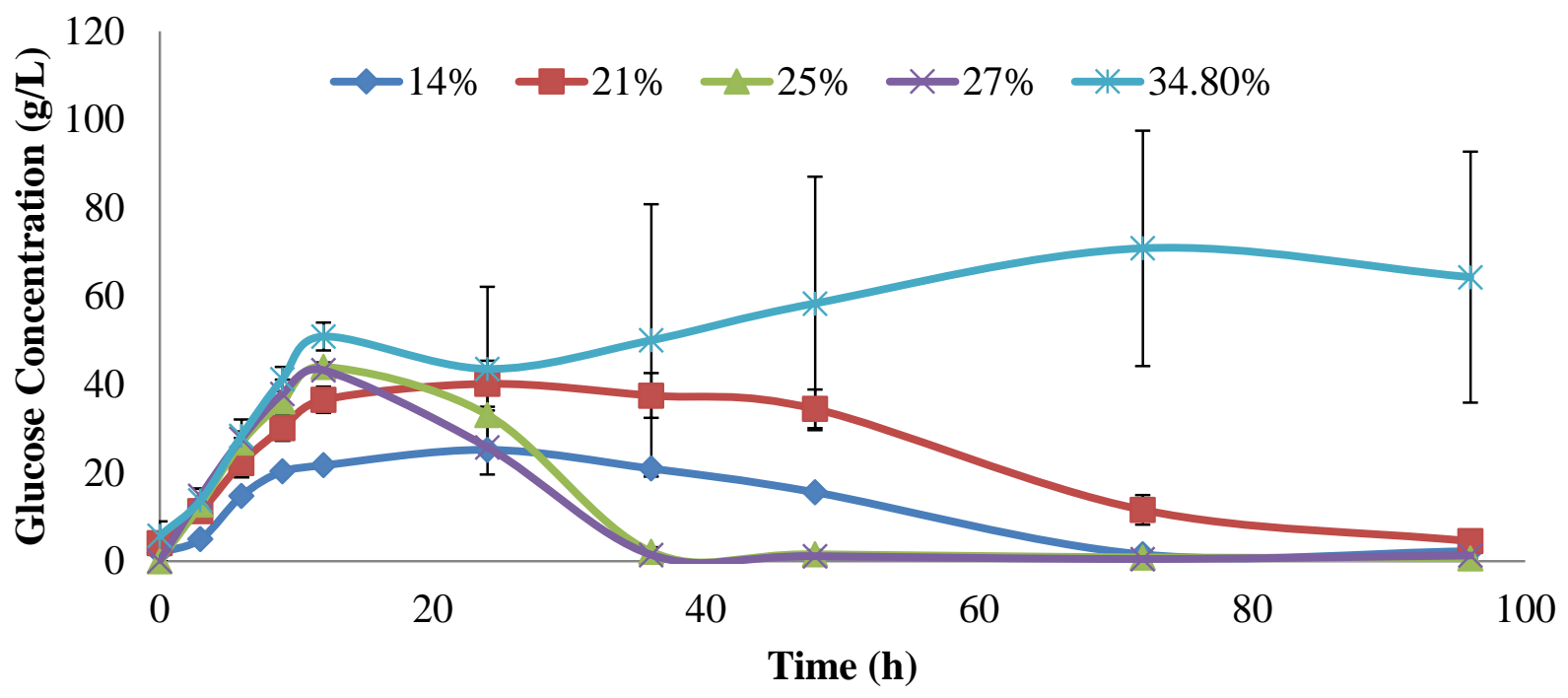

Figure 5. Residual Glucose Levels During Fed-batch Solid State SSF at Various SLRs.

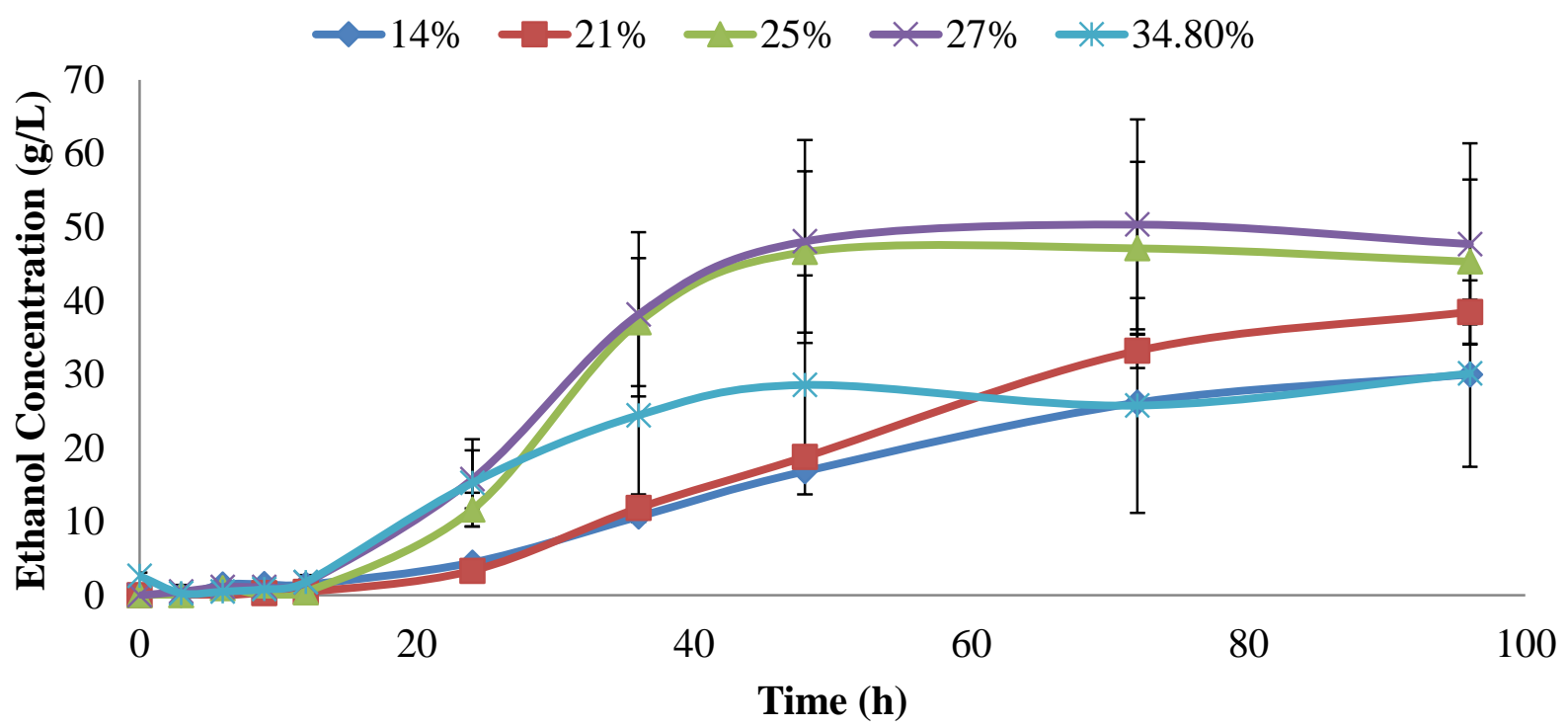

Figure 6. Ethanol Titers During Fed-batch Solid State SSF at Various SLRs. 


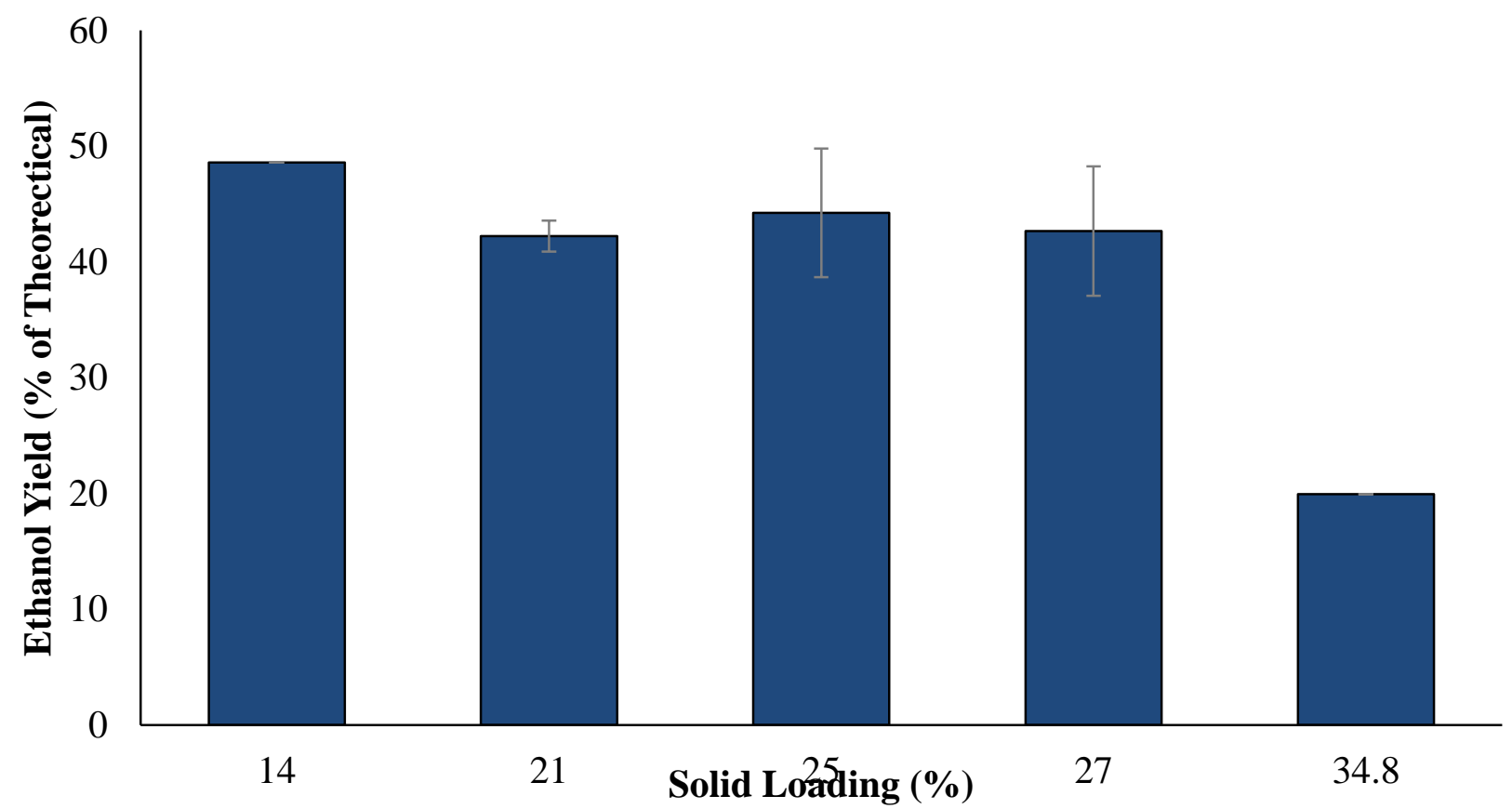

Figure 7. Maximum Ethanol Yield from Fed-batch Solid State SSF at Various SLRs.

Jorgensen et al [17] conducted a separate hydrolysis $\left(8 \mathrm{~h}\right.$ at $\left.50^{\circ} \mathrm{C}\right)$ of hot water treated wheat straw at $35 \%$ solids loading, using enzyme levels of $34 \%$ of the literature average. After $144 \mathrm{~h}$ fermentation they obtained $39 \%$ of the theoretical ethanol yield, compared to the $\sim 20 \%$ yield we obtained with a $19 \%$ enzyme dosage. Zhang et al [8] conducted fed-batch SSF of corncobs pretreated with dilute sulfuric acid, sodium hydroxide, and aqueous ammonia pretreatment or simple soaking in aqueous ammonia. At a final solids loading of $25 \%$ and using a cellulase dosage of $67 \%$ of the literature average, they obtained ethanol yields of $67.8 \%$ - $89 \%$. This compares to the $44 \%$ yield (or $60 \%$ if corrected for ethanol evaporative loss) we obtained at $25 \%$ SLR, but required three times more enzyme than the $22 \%$ dosage we used at this SLR. Thus enzyme dosage appears to play an even more critical role at higher SLRs, likely due to the increased viscosity that would reduce mass transfer $[18,19,20]$.

To further explore why ethanol yields were lower than expected during fed-batch SSF, $100 \mathrm{~g}$ quantities of the fermented slurry were mixed with $10,25,50$, and $100 \mathrm{ml}$ of buffer, and the flasks were incubated at $35^{\circ} \mathrm{C}$ for an additional $72 \mathrm{~h}$ at $250 \mathrm{rpm}$. To assess whether yeast nutrients were limiting, $100 \mathrm{~g}$ of fermented slurry was also incubated with $49 \mathrm{ml}$ of buffer and $1 \mathrm{~g}$ of yeast extract. Figure 8 shows ethanol yields from the undiluted and diluted samples for each initial SLR trail. As can be seen, adding yeast extract along with $50 \mathrm{ml}$ of water did not improve ethanol yields, thus indicating that nutrients were not limiting ethanol yields. Only a slight improvement in ethanol yield was noted when fermented material from the $25 \%$ solid loading rate trial was diluted and incubated an additional $72 \mathrm{~h}$. No benefit was observed in the $27 \%$ solid loading rate trials. The only significant increase in ethanol yield was when 100 $\mathrm{g}$ of the $21 \%$ solid loading rate material was diluted with $10 \mathrm{ml}$ of water and fermented $72 \mathrm{~h}$ more. Based on these findings it doesn't appear that water activity was the primary limiting factor. Instead we postulate that low enzyme activity may be the chief limitation, since residual sugar levels also remained low in these secondary fermentations of diluted samples. As noted by other investigators, a significant issue with cellulase enzymes in irreversible binding to biomass components $[18,19,20,21,22]$. 


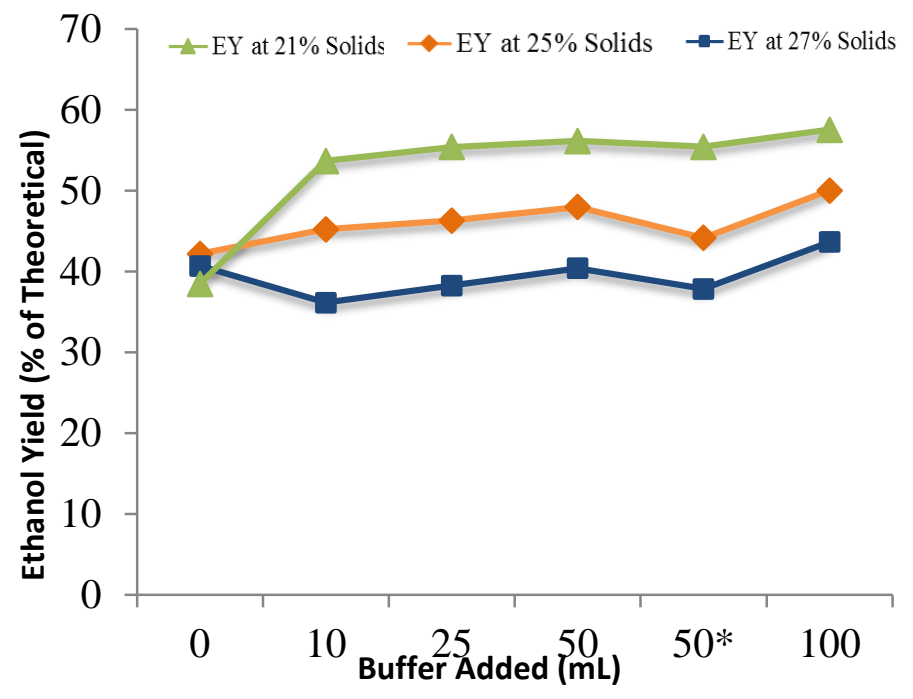

Figure 8: Ethanol Yield after Secondary Fermentation of Diluted Fermented Slurry

50*: $49 \mathrm{~mL}$ buffer+1 $\mathrm{g}$ of Yeast Extract

\section{Conclusion}

The goal of this project was evaluate fed-batch, solid state, simultaneous saccharification and fermentation (SSF) as an approach to reduce enzymes used in converting cellulose to ethanol and to increase then solids loading to maximize ethanol titer. During fedbatch submerged SSF of kraft pulp there were no significant differences between the final ethanol concentrations (47-52 g/l) or yield (77-83\%) when enzyme dosages were reduced from $133 \%$ to $33 \%$ of the average dosage calculated from the literature. It was possible to achieve a solids loading rate of $14 \%$ and still maintain adequate mixing.

During fed-batch saccharification trials in solid state bioreactor, $34.8 \%$ solids loading was achieved with an acceptable mixing rate, while reducing enzyme dosage to $19 \%$ of the literature average. Due to feedback inhibition of enzymes, however, glucose levels only reached $\sim 100 \mathrm{~g} / \mathrm{L}$, which was $35 \%$ of the theoretical yield. To prevent feedback inhibition $[4,5]$ fed-batch SSF trials were conducted under identical conditions. Due to apparent yeast inhibition caused by low water activity [4], the ethanol yield only rose to $20 \%$ of theoretical, while glucose levels rose to $70 \mathrm{~g} / \mathrm{L}$. We then evaluated performance at solid loading rates of 21,25 , and $27 \%$ and ethanol yields increased to $42-44 \%$, confirming that low water activity was at least partially responsible for low ethanol yields. However, in comparison to a submerged SSF trial at $14 \%$ SLR, we observed a $37 \%$ loss of ethanol from the solid state reactor due to evaporation. We also detected substantial levels of unhydrolyzed cellulose in these trials. We then further diluted the fermented slurry and conducted a secondary fermentation. This did not substantially improve ethanol yields or cellulose hydrolysis, suggesting that enzyme inactivation via irreversible binding may be responsible $[18,19,20,21,22]$.

\section{References}

[1] P.A. Gibbs, R.J. Seviour, F. Schmid. 2000. Growth of Filamentous Fungi in Submerged Culture: Problems and Possible Solutions. Critical Reviews in Biotechnology, 20:17-48.

[2] M.J. Zhang, F. Wang, R.X. Su, W. Qi, Z.M. He. 2009. Ethanol Production from High Dry Matter Corncob using Fed-batch Simultaneous Saccharification and Fermentation after Combined Pretreatment. Bioresource Technology, 101:4959-64.

[3]. L.R. Lynd, W.H. van Zyl, J.E. McBride, M. Laser. 2005. Consolidated bioprocessing of cellulosic biomass: an update. Current Opinion in Biotechnology, 16:577-583.

[4] R.C. Kuhad, G. Mehta, R. Gupta, K.K. Sharma. 2010. Fed batch Enzymatic Saccharification of Newspaper Cellulosics Improves the Sugar Content in the Hydrolysates and Eventually the Ethanol Fermentation by Saccharomyces cerevisiae. Biomass Bioenergy, 34:1189-94.

[5] B. Erdei, Z. Barta, B. Sipos, K. Reczey, M. Galbe, G. Zacchi. 2010. Ethanol Production from Mixtures of Wheat Straw and Wheat Meal. Biotechnology for Biofuels, 3:1-9.

[6] L. Camacho-Ruiz, N. Perez-Guerra, R.P. Roses 2003. Factors Affecting the Growth of Saccharomyces cerevisiae in Batch Culture and in Solid State Fermentation. Electronic Journal of Environmental, Agricultural and Food Chemistry, 2:531-542.

[7] A. Pandeya, C.R. Soccola, D. Mitchell. 2000. New Developments in Solid State Fermentation: IBioprocesses and Products. Process Biochemistry, 35:1153-1169.

[8] X.Y. Zhang, H. Mo, J. Zhang, Z.H. Li. 2003. A Solid-State Bioreactor Coupled with Forced Aeration and Pressure Oscillation. Biotechnology Letters, 25:417-20.

[9] C. Moukamnerd, M. Kino-oka, M. Sugiyama, Y. Kaneko, C. Boonchird, S. Harashima, H. Noda, K. Ninomiya, S. Shioya, Y. Katakura. 2010. Ethanol Production from Biomass by Repetitive Solid-State Fed-Batch 
Fermentation with Continuous Recovery of Ethanol. Applied Microbiology and Biotechnology, 88:87-94.

[10] W.R. Gibbons, C.A. Westby, T.L. Dobbs. 1986a. Intermediate-scale, Semicontinuous Solid-phase Fermentation Process for Production of Fuel Ethanol from Sweet Sorghum. Applied Environmental Microbiology, 51:115-22.

[11] W.R. Gibbons, and C.A. Westby. 1986b. Effect of Pulp pH on Solid Phase Fermentation of Fodder Beets for Fuel Ethanol Production. Biotechnology Letters, 8:657-662.

[12] C. Karunanithy, K. Muthukumarappan, W.R. Gibbons. 2013. Effect of extruder screw speed, temperature, and enzyme levels on sugar recovery from different biomasses. ISRN Biotechnology, DOI:10.5402/2013/942810.

[13] N.A. Bauer, and W.R. Gibbons. 2012. Saccharification versus Simultaneous Saccharification and Fermentation of Kraft Pulp. International Journal of Agricultural and Biological Engineering. 5:48-55.

[14] E. Tomas-Pejo, M. Ballesteros, J.M. Oliva, L. Olsson. 2010. Adaptation of the Xylose Fermenting Yeast Saccharomyces cerevisiae F12 for Improving Ethanol Production in Different Fed-batch SSF Processes. Journal of Industrial Microbiology and Biotechnology, 37:1211-20.

[15] M. Ballesteros, J.M. Oliva, P. Manzanares, M.J. Negro, I. Ballesteros I. 2002. Ethanol Production from Paper Material using a Simultaneous Saccharification and Fermentation System in a Fed-batch Basis. World Journal of Microbiology and Biotechnology, 8:559-61.

[16] C.M. Rochel, C.J. Dibble, J.J. Stickel. 2009. Laboratoryscale Method for Enzymatic Saccharification of Lignocellulosic Biomass at High-solids Loadings. Biotechnology for Biofuels, 2:1-11.
[17] H. Jorgensen, J. Vibe-Pedersen, J. Larsen, C. Felby. 2007. Liquefaction of Lignocellulose at High-solids Concentrations. Biotechnology and Bioengineering, 96:862-70.

[18] A.D. Eckard, K. Muthukumrarappan, W.R. Gibbons. 2011. Pretreatment of Extruded Corn Stover with Polyethylene Glycol to Enhance Enzymatic Hydrolysis: Optimization, Kinetics, and Mechanism of Action. BioEnergy Research. 5: 424438.

[19] A.D. Eckard, K. Muthukumrarappan, W.R. Gibbons. 2012a. Analysis of Casein Biopolymers Adsorption to Lignocellulosic Biomass as a Potential Cellulase Stabilizer. Journal of Biomedicine and Biotechnology, 1:1-11.

[20] A.D. Eckard, K. Muthukumrarappan, W.R. Gibbons. 2013a. Enzyme Recycling in a Simultaneous and Separate Saccharification and Fermentation of Corn Stover: A Comparision between the Effect of Polymeric Micelles of Surfactants and Polypeptides. Bioresource Technology, 132:202209.

[21] A.D. Eckard, K. Muthukumrarappan, W.R. Gibbons. 2012b. Modeling of Pretreatment Condition of Extrusion Pretreated Prairie Cordgrass and Corn Stover with Poly (oxyethylen (20) Sorbitan Monolaurate. Applied Biochemistry and Biotechnology, 167: 377-393.

[22] A.D. Eckard, K. Muthukumrarappan, W.R. Gibbons. 2013b. Enhanced Bioethanol Production from Pretreated Corn Stover via Multi-positive Effect of Casein Micelles. Bioresource Technology, 135:93102. 